\title{
The Invisible Hitchhiker
}

Murmurations:

Journal of

Transformative

Systemic

Practice

\section{Volume 3}

\section{Issue 1}

Autumn 2020

\section{Keywords:}

Black Lives Matter, pandemic, Covid-19, coronavirus, NHS, poetry

\section{Citation Link}

\section{Julia Jude}

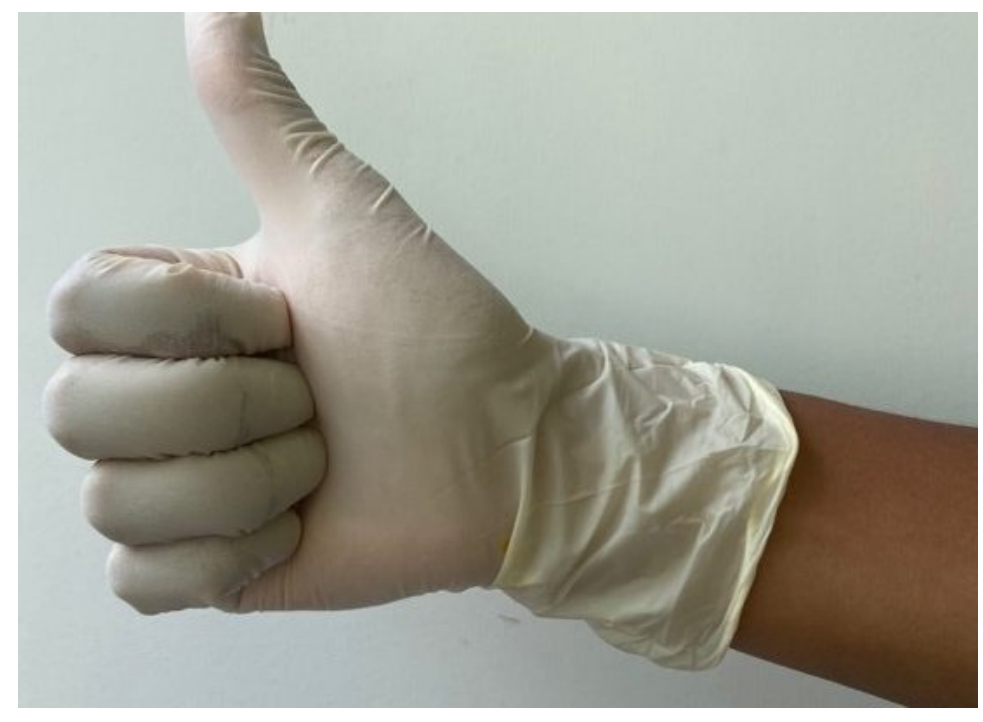

The invisible assailant

Closed our Schools

Workplace

Universities

Shops

Places of worship

Crushed movements

As countries rushed to close their borders

Catchy slogans cooked up by spin doctors

Poured on to our screen

Stay at home and protect the NHS

Stay and home and self-isolate

Stay at home and shield the vulnerable

Stay at home and keep safe

Stay at home had no limits

Hunt was on

To fill the cupboards

To step up to the challenge 
To do our bit to protect our family and loved ones

To do our bit to protect the NHS

To be responsible and attend to civic duties

And those who cross that line beware

Be prepared to be humiliated

Those who tried to attend to their basic needs

Be prepared to be shamed and photographed for all to see

The bullies

Media Mafia stand ready to gang up

On what they called those 'shameless and selfish shoppers'

Wheeling round trollies loaded with loo rolls and sanitisers

Thoughtless heathens

Roared the press

Morals have been abandoned

Maybe Hobbs was right

Now what

Streets are quiet

No cars

Few buses

Windows transformed by children's painting of rainbows

Melancholy is the new urban landscape

Air is cleaner

Birds can be heard tweeting

No longer drowned by urban living

Spring has arrived

Bringing with her a carnival of colours

Red, yellow, pink and purple

Bluebells paint our woodlands

Greeting sunlight

Before the arms of nature

Reveal their foliage

Forcing a hasty retreat.

The warmth of April sun

Release the pungent smell of nature

Wisterias show off their dazzling clumps of lilac petals

The senses are tingling

Thirsty for a touch of nature

The greenery of the local parks

Beckons its resident

Life has not lost its sweetness 
Mind, soul and body nestled in the arm of nature

Heartbeat gentle

Fear recedes and withdraws

A stillness

A pause

A release of tension

A rainbow appears

Hope dips its toes and comes out to play

A horizon of plenty appears

Bodies feel the urge to flea

In this wonderland

like the swallow that guilds through skies

Visiting worlds far and near

Not hampered by passports or borders

The touch of air and wind

Moves around me

Greeting me softly

Like water I feel its presence

But it refuses to be captured

It's not for sale.

This moment treasured is no idyll

My hour in the park has come to an end

Like Cinderella, I scurry back home

And bid farewell to nature for another day

In retreat

I long for solace and shelter in the countryside

The intimate spaces of city dwelling no longer desirable

Lockdown in city blocks has become a site of claustrophobia

Nobody is safe from the invisible killer

But it does not stop urban dwellers

Dreaming of country living

Silence descends

Loneliness hits hard

Joy and hope retire

The pandemic beast comes back to roam

Seeking souls unprotected by the spirits

Bodies touched by alcohol

Bodies unshielded

Bodies unprotected by loved ones 
Bodies weighted down by illness

All prey to the beast

Whose claws

Spares no mercy

Those distant, near and far

Look on powerless

As space looking aliens

Care for their loved one

The invisible hitchhiker

Stands guard ready to rip out lungs of bodies

Leaving loved ones unable to mourn their dead

Stay at home and protect the NHS

What if homes are the taker of life

An ugly space where abuse reins

Behind closed doors

Where voices are muffled and drowned

Movement restricted

By a look of the eye,

By clenched fist

By kitchen knives

Tools regulating response

Allies of tyrannical bodies

What if home is deprived of space

Not fit for purpose

Bearing witness of empty food cupboards

Deprived of outside spaces to retreat to

Deprived of technology

Dependent on electrical meters

Top up schemes to keep family connected

What if homes used to rely on food banks

To bring food to the tables

What if home no longer feels like home

Stay at home and save lives

Whose lives?

BAME

Poor

Immigrants

Elderly

Disabled

Homeless 


\section{Refugees}

Where does the moral compass lie?

The invisible hitchhiker

Touring the globe

Unveils the naked truths

Of the haves and have nots

Of the Oppressed

Ghosts of slavery

Poverty and slum clusters

There is disquiet as it moves slowly

Over the suspension of the care Act

The enormity of loss suffered

Loss of not being able to physically touch

Loss of not saying goodbye

Your photographs remain as evidence of your existence

Stay with me in my grief

As I retreat in my inner

Alone once more

Wandering around each room

In search of your presence

Empty head robbed of your companion

The salty sea tears touch my mouth

Oh, this grief is hard to bear

Bring me love and hope

Bring me kindness and compassion

Relieve this torment of mind and body

Heal the past and restore faith in future

Let there be a tomorrow

But when tomorrow comes

How will we recall these moments?

When a vaccine puts this pandemic to sleep

I want to hold on

To compassion

Empathy

The thank you notes placed on the bins and letterboxes I want to remember friends that I kept in touch with I want to remember my baking that saved me when soberness took control I want to remember my friendship with nature 
The weekly applause for front line workers

That lifted our spirits and connected us to a sense of community

That we did not know that we had

I want to remember the empty spaces created

To reflect and do things differently

I want to remember the vulnerability of BAME communities

The voices that got left behind

I want to remember the importance of being present with

Another human being

Want to remember the importance of staying hopeful even

When you feel that you can't go on

Maybe this will give me a new sense of direction

Remembering the past to imagine a new future

\section{Citation}

Jude, Julia (2020). The Invisible Hitchhiker. Murmurations: Journal of Transformative Systemic Practice, 3, 1, 712. https://doi.org/10.28963/3.1.4 